\title{
FURIN Gene
}

National Cancer Institute

\section{Source}

National Cancer Institute. FURIN Gene. NCI Thesaurus. Code C18603.

This gene plays a role in cell-cell signaling and signal transduction. 